\title{
Rigid polyurethane foams with antibacterial properties modified with pine oil ${ }^{*}$
}

\author{
Anna Strąkowska ${ }^{1), * *)}$, Sylwia Członka ${ }^{1)}$, Karolina Miedzińska ${ }^{1)}$, Krzysztof Strzelec ${ }^{1)}$ \\ DOI: dx.doi.org/10.14314/polimery.2020.10.4
}

\begin{abstract}
The effect of the amount of pine needle oil on the properties of rigid polyurethane (RPUF) foams was investigated. The influence of pine needle oil content on the cellular morphology, physical, mechanical, and antibacterial properties of RPUF was evaluated. The addition of pine needle oil had decreased the dynamic viscosity and processing times of polyurethane (PUR) systems. It was found that the foams containing $5 \mathrm{wt} \%$ of pine needle oil had better mechanical properties, e.g. compressive strength, flexural strength, and impact strength. RPUF containing the highest concentration of pine needle oil, such as $15 \mathrm{wt} \%$, possessed improved antibacterial activity against E. coli and S. aureus. This study confirmed that the use of pine needle oil is an effective approach to the production of RPUFs with antibacterial activity.
\end{abstract}

Keywords: polyurethane foams, pine needle oil, antibacterial properties, mechanical properties.

\section{Sztywne pianki poliuretanowe o właściwościach antybakteryjnych modyfikowane olejkiem sosnowym}

Streszczenie: Zbadano wpływ dodatku olejku sosnowego na właściwości użytkowe sztywnych pianek poliuretanowych (RPUF): strukturę, właściwości fizyczne, mechaniczne i antybakteryjne. Układy poliuretanowe (PUR) modyfikowane dodatkiem olejku sosnowego charakteryzowały się mniejszą lepkością dynamiczną oraz krótszymi czasami syntezy niż układy bez dodatku. Najlepsze właściwości mechaniczne, w tym m.in. wytrzymałość na ściskanie, zginanie trójpunktowe i udarność, wykazywała pianka poliuretanowa zawierająca 5\% mas. olejku sosnowego. Najlepszymi właściwościami antybakteryjnymi (względem E. coli oraz S. aureus) odznaczała się pianka zawierająca 15\% mas. olejku sosnowego. Stwierdzono, że modyfikacja układów poliuretanowych dodatkiem olejku sosnowego umożliwia otrzymanie RPUFs o właściwościach antybakteryjnych.

Słowa kluczowe: pianki poliuretanowe, olejek sosnowy, właściwości antybakteryjne, właściwości mechaniczne.

Polyurethanes (PURs) are a class of materials used in many industries, from the automotive industry to biomaterials $[1,2]$. The range of possibilities to modify their properties is very wide and is mainly based on the introduction of various functional additives at the stage of their preparation [3-5]. A wide range of polyurethane applications makes it possible to constantly develop green and sustainable products based on them. For example, a lot of research has been done to develop polyurethane-based materials with antimicrobial properties [6-8]. The demand for antimicrobial products is reported in many

\footnotetext{
1) Lodz University of Technology, Chemical Department, Institute of Polymer and Dye Technology, Stefanowskiego 12/16, 90-924 Łódź, Poland.

*) Material contained in this article was presented at the Science and Technology Conference on "Polyurethanes 2019", Ustroń, Poland, 13-16 October 2019.

**) Author for correspondence: anna.strakowska@p.lodz.pl
}

different fields, for example in the production of medical devices, packaging, automotive, household appliances, in the hospital environment, and the care of infants.

The main concepts for the production of antibacterial polyurethane foams are primarily based on the introduction of biocidal additives at the preparation stage [9-11]. However, various important aspects should be considered before using these additives in the composite. Important factors to consider when using a germicidal substance include compound compatibility with a matrix material, leaching of the functional substance, its chemical stability at different temperatures, and its effect on various microorganisms [12, 13].

From among the various types of modifying substances, there are still no publications that would examine the effect of pine needle oil on useful properties, in particular antibacterial RPUFs. Chemically, pine oil (Pini sylvestris aetheroleum) consists mainly of $\alpha$-terpineol and other cyclic terpene alcohols. It may also contain terpene hydrocar- 
bons, ethers, and esters. The exact composition depends on various factors, such as the variety of pine from which it is produced and the parts of the tree used [14].

The lipophilic nature of the oils makes it easier for them to pass through the bacterial wall and then coagulate the cytoplasm. Then they cause increased loss of cell membrane ions, which leads to disruption of the proton pump and reduction of intracellular adenosine triphosphate (ATP). As a result, infected bacteria break down. Therefore, the results of scientific studies on the most essential oils indicate their bactericidal properties [15].

To the best of our knowledge, pine oil as an antibacterial substance in PUR foams has not been used so far. Given the unique properties of pine oil and its lipophilic nature, it seems appropriate to use it as a modifier for new bio-based composite foams. It is expected that

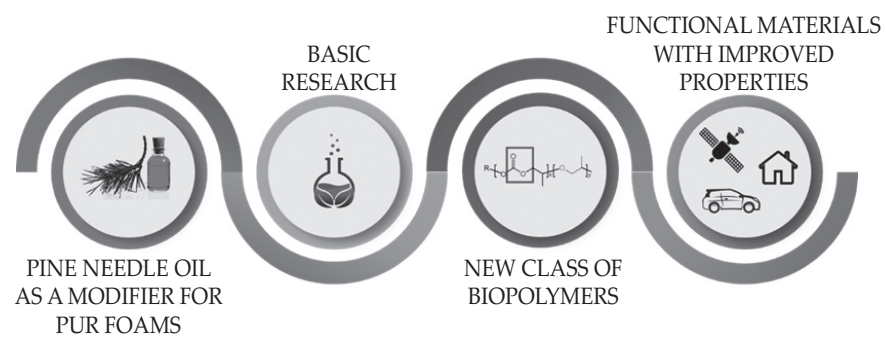

Fig. 1. Graphical abstract of obtaining bio-based PUR foam; source own study

the introduction of pine oil may in particular improve the antibacterial properties of the materials obtained (Fig. 1).

The current research focuses on examining the effect of pine oil as a natural addition on the synthesis kinetics and structure of the obtained foams, their mechanical and hydrophobic as well as antibacterial properties. Obtained biologically active porous PUR materials containing natural pine oil can be used in the medical industry (protective systems, antimicrobial isolation in biomedical devices and antimicrobial packaging, etc.).

\section{EXPERIMENTAL PART}

\section{Materials}

The water-blown RPUFs used in this study were obtained from a two-component system supplied by Purinova Sp. z o.o., after mixing the polyol (Izopianol 30/10/C) and the diphenylmethane diisocyanate (Purocyn B). The polyol is a mixture of components containing polyester polyol (hydroxyl number ca. $230-250 \mathrm{mgKOH} / \mathrm{g}$, the functionality of 2), catalyst ( $N, N$-dimethylcyclohexylamine), flame retardant [tris(2-chloro-1-methylethyl) phosphate], a chain extender (1,2-propanediol) and water as a blowing agent. Pine needle oil was purchased from Merck. According to the supplier's information, it may consist of oils from various pine species, such as Pinus elliottii, Pinus palustris, Pinus taeda, Pinus serotina, and Pinus clausa.

\section{Manufacturing of RPUFs}

RPUFs containing pine needle oil in an amount of 5 , 10 and $15 \mathrm{wt} \%$ based on the weight of the polyol were obtained as follows. The adequate amount of oil was added to the Izopianol 30/10/C and the mixture (component A) was homogenized with an overhead stirrer at $1000 \mathrm{rpm}$ under ambient conditions for approximately 30 s. Purocyn B (component B) was added to component $A$ and the mixture was stirred for $15 \mathrm{~s}$ at a speed rate of $1800 \mathrm{rpm}$. Following the information provided by the supplier, the ingredients were mixed in the ratio of 100:160 (ratio of component A to component B). The whole system was mixed in buckets with a substrate diameter of $15 \mathrm{~cm}$ and a height of $23 \mathrm{~cm}$. After mixing in the open mold, the mixture was allowed to expand freely in the vertical direction. The foams obtained had a volume about $30 \%$ larger than that of the container. RPUFs were conditioned at room temperature for $24 \mathrm{~h}$. After this time, samples were cut with a band saw into appropriate shapes (determined by obligatory standards listed below in the further text) and their physio-mechanical properties were investigated.

\section{Methods of testing}

The viscosity of pine oil and PUR systems was determined following ISO 2555:2018. The measurement was performed using Viscometer DVII+ (Brookfield, Germany) in the function of shear $\left(0.5-100 \mathrm{~s}^{-1}\right)$. The viscosity was evaluated in ambient temperature.

The biocidal activity was assessed using a qualitative method by the methodology described in PN-EN ISO 20645:2006 (bacteria) and in accordance with PN-EN ISO 14119:2005 (fungi). Antimicrobial activity of pine oil was determined following the guidelines of the ATCC Test Method 100. The antimicrobial activity was examined against selected bacteria $-E$. coli and S. aureus. The selected bacteria were inoculated on the surface of PUR foams and after 24 hours of contact, the percentage reduction of the microorganism caused by the antibacterial agent was determined. The initial suspension of $E$. coli and S. aureus was $76 \cdot 10^{6} \mathrm{CFU} / \mathrm{cm}^{3}$.

The morphology and cell size distribution of foams were examined from the cellular structure images of foam which were taken using JEOL JSM-5500 LV scanning electron microscopy (JEOL Ltd., USA). All microscopic observations were made in the high-vacuum mode and at the accelerating voltage of $10 \mathrm{kV}$. Samples were scanned in a direction parallel to the foam growth. The average pore diameters, walls thickness, and pore size distribution were calculated using ImageJ software (Media Cybernetics Inc.). 
The apparent density of foams was determined accordingly to ASTM D1622 (equivalent to ISO 845). The densities of 5 specimens per sample were measured and averaged.

The compressive strength of foams was determined accordingly to the ASTM D1621 (equivalent to ISO 844) using Zwick Z100 Testing Machine (Zwick/Roell Group, Germany) with a load cell of $2 \mathrm{kN}$ and the speed of $2 \mathrm{~mm} / \mathrm{min}$. Samples of the specified sizes were cut with a band saw in a direction parallel and perpendicular to the foam growth direction. Then, the analyzed sample was placed between two plates and the compression strength was measured as a ratio of the load causing a $10 \%$ deformation of sample cross-section in the parallel and perpendicular direction to the square surface. The result was averaged 5 measurements per each sample.

Impact test was carried out in agreement with ASTM D4812 on the pendulum $0.4 \mathrm{~kg}$ hammer impact velocity at $2.9 \mathrm{~m} / \mathrm{s}$ with the sample dimension of $10 \times 10 \times 100\left(\mathrm{~mm}^{3}\right)$. All tests were performed at room temperature. At least five samples were prepared for the tests.

Three-point bending test was carried out using Zwick Z100 Testing Machine (Zwick/Roell Group, Germany) at room temperature, according to ASTM D7264 (equivalent to ISO 178). The tested samples were bent with a testing speed of $2 \mathrm{~mm} / \mathrm{min}$. Obtained flexural stress at break results for each sample were expressed as a mean value. The average of 5 measurements per each type of composition was accepted.

Surface hydrophobicity was analyzed by contact angle measurements using the sessile-drop method with a manual contact angle goniometer with an optical system OS-45D (Oscar, Taiwan) to capture the profile of a pure liquid on a solid substrate. A water drop of $1 \mathrm{~mm}^{3}$ was deposited onto the flat porous surface cut out from the inside of the foam using a micrometer syringe fitted with a stainless steel needle. The contact angles reported are the average of at least ten tests on the same sample.

Water absorption of the RPUFs was measured according to ASTM D2842. Samples were dried for $1 \mathrm{~h}$ at $80^{\circ} \mathrm{C}$ and then weighed. The samples were immersed in distilled water to a depth of $1 \mathrm{~cm}$ for $24 \mathrm{~h}$. Afterward, the samples were removed from the water, held vertically for $10 \mathrm{~s}$, the pendant drop was removed and then blotted between dry filter paper (Fisher Scientific, USA) at $10 \mathrm{~s}$ and weighed again. The average of 5 specimens was used.

\section{RESULTS AND DISCUSSION}

The viscosity of the PUR mixture is a crucial parameter that affects the foaming process and further, the cellular morphology of PUR foams [16]. Due to this, the viscosity of PUR systems has been evaluated in the function of the shear rate (0.5-100 rpm).

The results presented in the Table 1 indicate that the incorporation of pine oil into the PUR system affects the viscosity of the resulted mixtures.
T a b l e 1. Effect of pine oil on the kinetics of the foaming process

\begin{tabular}{c|c|c|c}
\hline \multirow{2}{*}{ Sample } & \multicolumn{3}{|c}{ Dynamic viscosity $\eta, \mathrm{mPa} \cdot \mathrm{s}$} \\
\cline { 2 - 4 } & $0.5 \mathrm{rpm}$ & $50 \mathrm{rpm}$ & $100 \mathrm{rpm}$ \\
\hline Pine oil & 650 & 350 & 280 \\
PU-0 & 730 & 420 & 360 \\
PU-5 & 720 & 450 & 320 \\
PU-10 & 680 & 410 & 310 \\
PU-15 & 670 & 390 & 305 \\
\hline
\end{tabular}

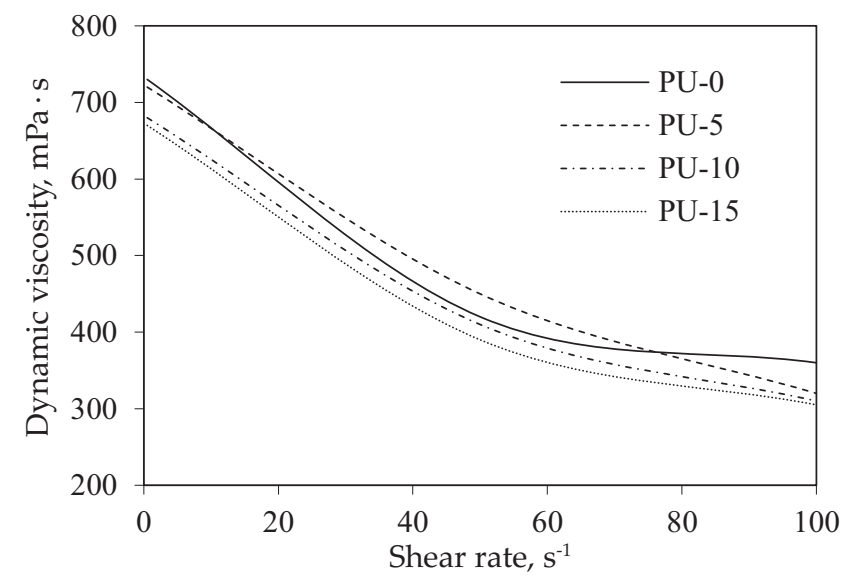

Fig. 2. Viscosity as a function of shear rate

With the addition of 5,10 , and $15 \mathrm{wt} \%$ of pine oil, the dynamic viscosity decreases by 2,7 , and $8 \%$, when compared with the unmodified system (without the addition of pine oil). Regardless of the weight ratio of the pine oil in the PUR system, each of the modified systems exhibits similar viscosity characteristics, which is typical for pseudoplastic liquid (Fig. 2).

Under shear strain, the viscosity of the PUR systems rapidly decreases, and then, the relationship between the shear ratio and the dynamic viscosity becomes almost linear. Based on this result, all PUR mixture should be classified as shear-thinning liquids, and this behavior is also in line with the results reported in previous studies [17, 18].

An important issue regarding PUR production is the appropriate processing properties of the polymer. RPUFs synthesis reaction is highly exothermic, therefore the temperature of the reaction mixture was measured during the growth of foams. Also, the rate of temperature increase indicates the activity of the reaction mixture associated with the reactivity of the components of the mixture. As shown in the Table 2, the introduction of pine oil into the PUR system increases the activity of the reaction mixture, which confirms the increase in $T_{\max }$ during the foaming process. The temperature increases by about $4^{\circ} \mathrm{C}$ after entering $5 \mathrm{wt} \%$ of oil and increases evenly after each increase in the amount of oil up to a temperature of $142^{\circ} \mathrm{C}$ for $15 \mathrm{wt} \%$ of the modifier.

Increasing the reactivity of the system due to the presence of pine needle oil is also manifested by an increase 
$\mathrm{T}$ a b 1 e 2. Effect of pine oil on the kinetics of the foaming process and structural parameters of RPUFs

\begin{tabular}{c|c|c|c|c|c|c}
\hline Sample & $\begin{array}{c}\text { Temperature } \\
{ }^{\circ} \mathrm{C}\end{array}$ & $\begin{array}{c}\text { Cream time } \\
\mathrm{s}\end{array}$ & $\begin{array}{c}\text { Extension time } \\
\mathrm{s}\end{array}$ & $\begin{array}{c}\text { Tack-free time } \\
\mathrm{s}\end{array}$ & $\begin{array}{c}\text { Cell size } \\
\mu \mathrm{m}\end{array}$ & $\begin{array}{c}\text { Wall thickness } \\
\mu \mathrm{m}\end{array}$ \\
\hline PU-0 & $130 \pm 2$ & $39 \pm 3$ & $225 \pm 8$ & $335 \pm 9$ & $272 \pm 8$ & $62 \pm 4$ \\
PU-5 & $135 \pm 3$ & $37 \pm 2$ & $216 \pm 10$ & $336 \pm 8$ & $282 \pm 7$ & $62 \pm 4$ \\
PU-10 & $138 \pm 3$ & $35 \pm 2$ & $210 \pm 9$ & $340 \pm 9$ & $290 \pm 6$ & $59 \pm 3$ \\
PU-15 & $142 \pm 2$ & $35 \pm 2$ & $208 \pm 9$ & $348 \pm 9$ & $312 \pm 7$ & $55 \pm 3$ \\
\hline
\end{tabular}

in the speed of foam growth processes, wherewith the increase in the amount of oil, both the cream and the extension time was shorter compared to the reference system. This relationship is mainly associated with the fact that the addition of oil reduces the viscosity of modified systems, which in turn may increase the rate of isocyanate conversion during the reaction at an early stage. Also, lowering the viscosity of the system causes an increase in the mobility of the molecules, which leads to a shortening of cream and the extension time. In contrast, modified composites have a longer tack-free time compared to PU-0, which indicates that pine oil extends the cure time.

One of the most important parameters of foamed PUR materials is the cell structure. In the case of RPUFs, it is strived to obtain products with the largest possible

a)

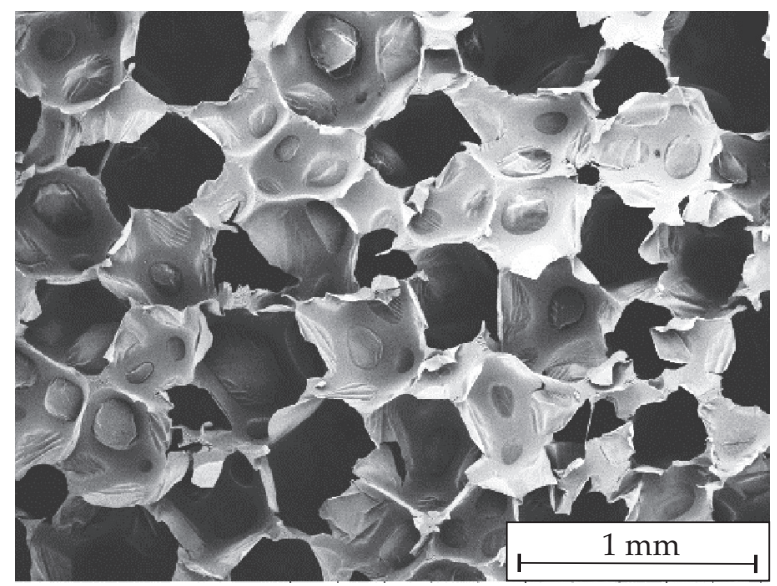

c)

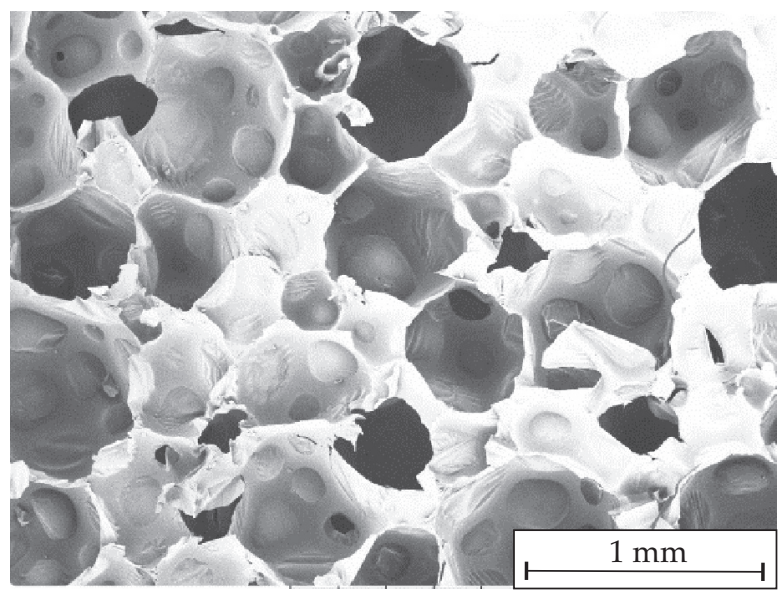

number of closed cells, the presence of which provides them with adequate mechanical and thermal insulation properties. The cell structure of the products obtained depends mainly on the initial viscosity of the reaction mixture and the presence of additives.

As observed on the reference foam micrograph (Fig. 3a), cell size and cell distribution are almost uniform, and the foam consists of closed cells with a small number of cells with broken walls. RPUF micrographs with an increased weight percentage of pine oil are shown in Figs. $3 b$ and $3 c$. After the addition of the modifier, the overall cell structure became less homogeneous and the cell size increased. An explanation can be found in reducing the viscosity of the reaction mixture due to the addition of pine oil, which affected the growth kinetics and easier expansion of the foams.

b)

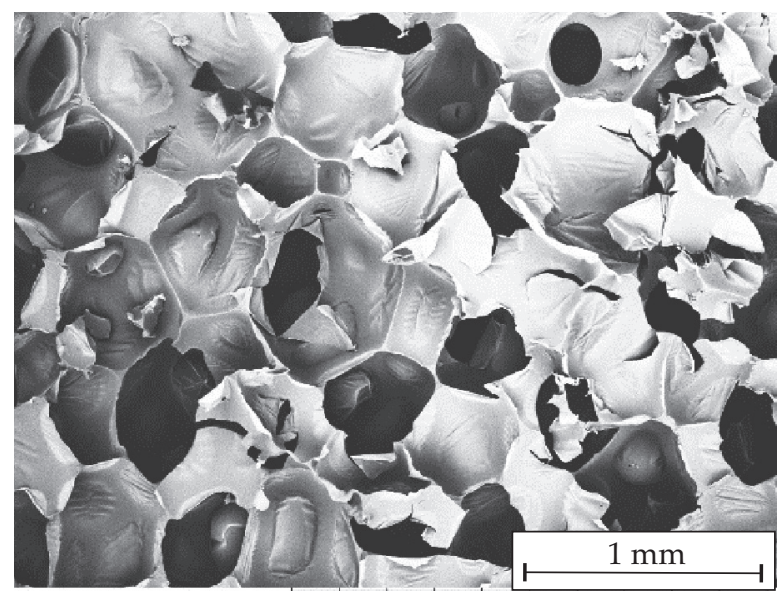

d)

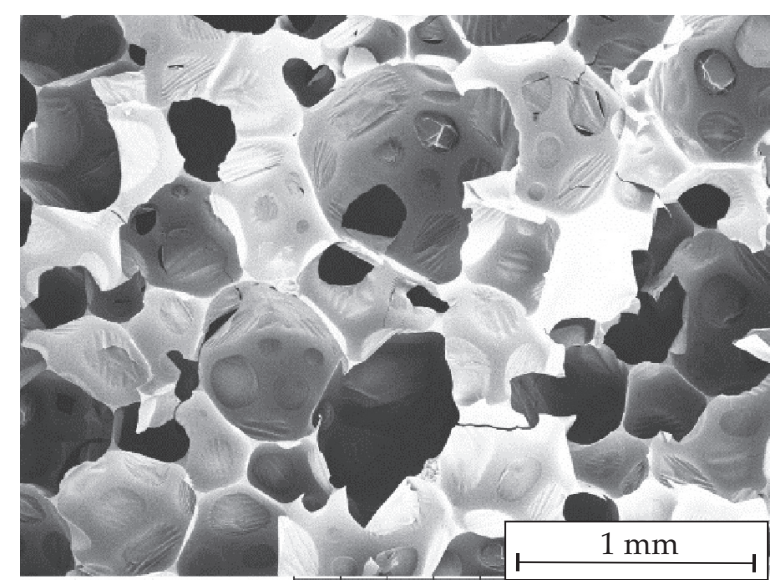

Fig. 3. Morphology of: a) PU-0, b) PU-5, c) PU-10, d) PU-15 
a)

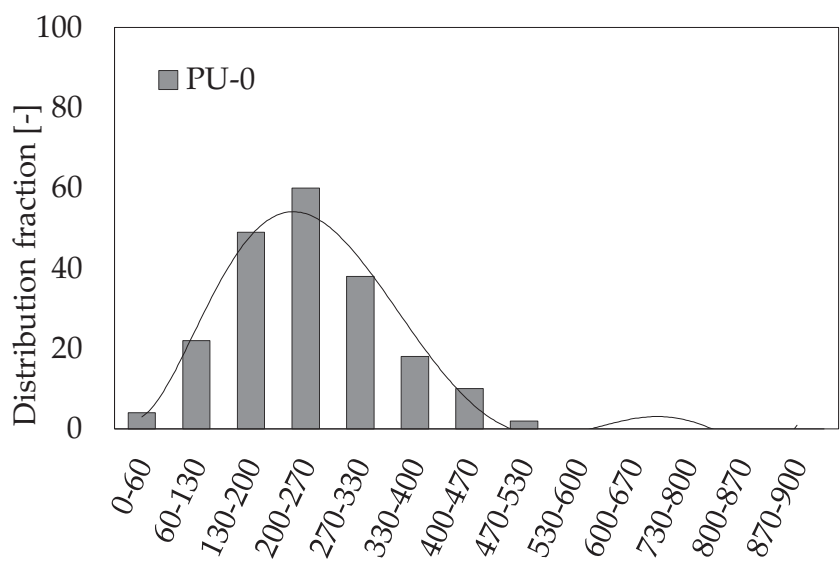

c)

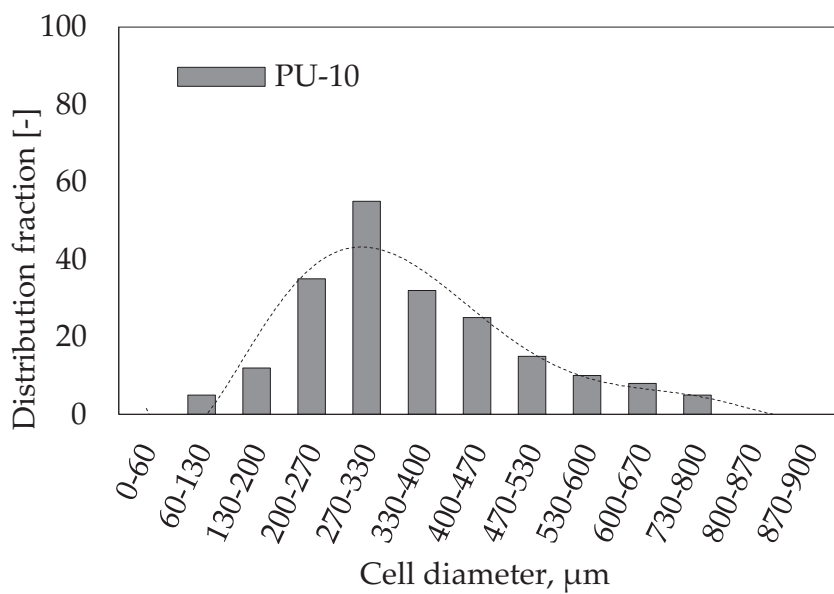

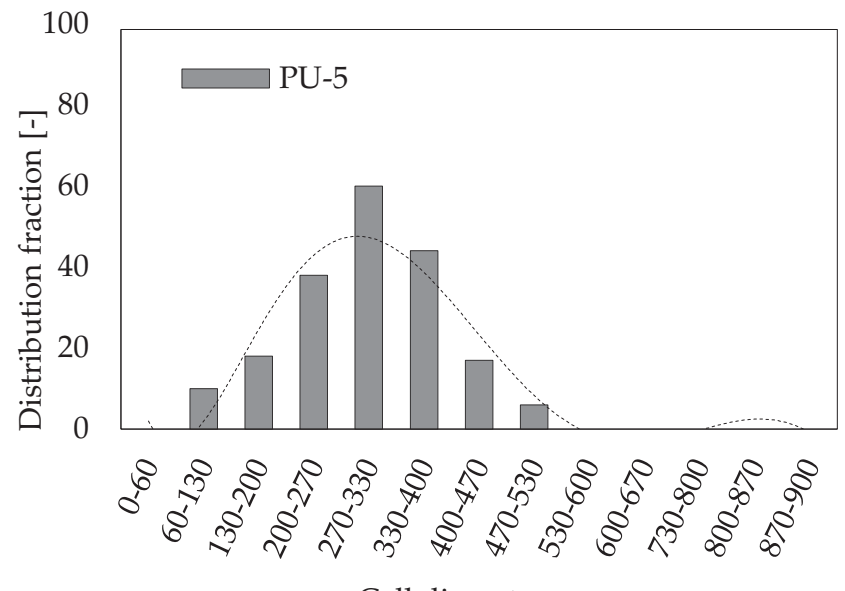

d)

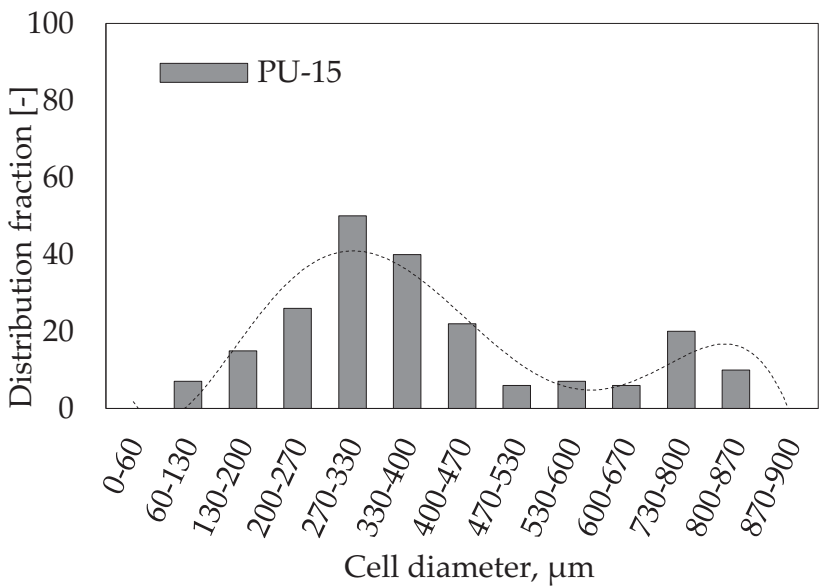

Fig. 4. Cell size distributions of: a) unmodified RPUFs and modified with pine oil in: b) $5 \mathrm{wt} \%$, c) $10 \mathrm{wt} \%$, d) $15 \mathrm{wt} \%$

Table 2 shows the average cell sizes for prepared PUR foams. The addition of pine oil to the PUR matrix leads to an increase in cell size, which can also be seen in the SEM pictures presented in Fig. 3. In addition, the thickness of the walls is also reduced, which indicates increased expansion.

Comparing Fig. $4 \mathrm{a}$ from Fig. $4 \mathrm{~b}-\mathrm{d}$, it is evident that the introduction of an oily substance with a lower viscosity than polyol results in larger cells, but also a less homogeneous pore structure compared to the reference sample. For unmodified RPUF, most pores are in the range 130-330 nm. In the case of RPUFs modified with pine oil, it can be seen that as its content increases, the pore size distribution also increasing, and finally at $15 \mathrm{wt} \%$ of pine oil two pore populations can be distinguished: with a larger number of cells with a diameter of about $270-400 \mathrm{~nm}$ and a smaller population with a size of about 730-800 nm.

The chemical composition of pine needles oil includes, e.g. $\alpha$-terpineol (30\%), linalool (24\%), limonene (17\%), and eugenol $(2 \%)$, which show a strong antimicrobial activity [19]. To examine the antibacterial activity of pine oil incorporated into PUR foams, the selected bacteria E. coli and S. aureus, were inoculated into the surface of PUR foams containing 5, 10 and $15 \mathrm{wt} \%$ of pine oil. The growth of the colonies was determined based on the dif- ference between the count of bacteria colony measured at the moment of inoculation and after 24 hours of inoculation. The results are presented in Table 3.

According to the results the count of E. coli and $S$. aureus decrease after 24 hours which confirms the antimicrobial behavior of pine oil in the PUR foams. The antimicrobial activity against $E$. coli and S. aureus is observed only in the case of PU-15 containing the highest weight ratio of pine oil. The addition of 5 and $10 \mathrm{wt} \%$ of pine oil provides an insignificant improvement of antimicrobial activity against $S$. aureus, however, no microbial activity is observed against $E$. coli. The addition of $5 \mathrm{wt} \%$ of pine oil does not improve the antimicrobial activity in any case, due to the low concentration of pine oil in the PUR composite. All the recounts after $24 \mathrm{~h}$ showed a greater quantity of bacteria. The results confirmed that the natural, antibacterial essential oil of pine can be incorporated into polymeric materials and retain their inhibitory effect against microbial growth, however, the concentration of the oil should be sufficient to provide such an effect, e.g. 15 wt \%. Thanks to this, the production of PUR foams with antimicrobial properties is possible.

Apparent density is one of the most important parameters affecting the physical, mechanical and thermal 
T a b l e 3. Microbial activity of PUR foams against Staphylococcus aureus and Escherichia coli

\begin{tabular}{c|c|c|c|c}
\hline \multirow{2}{*}{ Sample } & \multicolumn{2}{|c|}{ Suspension of S. aureus, CFU $/ \mathrm{cm}^{3}$} & \multicolumn{2}{c}{ Suspension of . coli, CFU/cm ${ }^{3}$} \\
\cline { 2 - 5 } & Initial & After 24 hours of exposure & Initial & After 24 hours of exposure \\
\hline PU-0 & $76 \cdot 10^{6}$ & $84 \cdot 10^{6}$ & $76 \cdot 10^{6}$ & $86 \cdot 10^{6}$ \\
PU-5 & $76 \cdot 10^{6}$ & $80 \cdot 10^{6}$ & $76 \cdot 10^{6}$ & $81 \cdot 10^{6}$ \\
PU-10 & $76 \cdot 10^{6}$ & $72 \cdot 10^{6}$ & $76 \cdot 10^{6}$ & $80 \cdot 10^{6}$ \\
PU-15 & $76 \cdot 10^{6}$ & $19 \cdot 10^{5}$ & $76 \cdot 10^{6}$ & $12 \cdot 10^{5}$ \\
\hline
\end{tabular}

T a b l e 4. Apparent density and mechanical properties of RPUFs

\begin{tabular}{c|c|c|c|c|c|c}
\hline Sample & $\begin{array}{c}\text { Apparent } \\
\text { density } \\
\mathrm{kg} / \mathrm{m}^{3}\end{array}$ & $\begin{array}{c}\text { Compressive } \\
\text { strength } \\
\text { (paralel) } \\
\mathrm{kPa}\end{array}$ & $\begin{array}{c}\text { Compressive } \\
\text { strength } \\
\text { (perpendicular) } \\
\mathrm{kPa}\end{array}$ & $\begin{array}{c}\text { Flexural } \\
\text { strength } \\
\mathrm{MPa}\end{array}$ & $\begin{array}{c}\text { Elongation } \\
\%\end{array}$ & $\begin{array}{c}\text { Impact strength } \\
\mathrm{kJ} / \mathrm{m}^{2}\end{array}$ \\
\hline PU-0 & $35 \pm 1$ & $260 \pm 7$ & $148 \pm 5$ & $0.420 \pm 0.008$ & $10.7 \pm 0.1$ & $0.35 \pm 0.01$ \\
PU-5 & $33 \pm 1$ & $271 \pm 8$ & $155 \pm 6$ & $0.418 \pm 0.009$ & $10.9 \pm 0.2$ & $0.32 \pm 0.01$ \\
PU-10 & $31 \pm 1$ & $258 \pm 6$ & $139 \pm 5$ & $0.415 \pm 0.007$ & $11.3 \pm 0.1$ & $0.31 \pm 0.01$ \\
PU-15 & $30 \pm 1$ & $224 \pm 6$ & $132 \pm 4$ & $0.400 \pm 0.007$ & $11.7 \pm 0.2$ & $0.27 \pm 0.01$ \\
\hline
\end{tabular}

properties of RPUF, which in line determine their performance and application. The density values of the foams are shown in the Table 4.

As might be expected, the apparent density is reduced after modifying the system with pine oil. PU-0 has an apparent density of $35 \mathrm{~kg} / \mathrm{m}^{3}$ and decreases to 33, 31, and $30 \mathrm{~kg} / \mathrm{m}^{3}$ for samples with 5,10 , and $15 \mathrm{wt} \%$ of oil, respectively. Such density differences were reflected in the results of compressive strength at $10 \%$ deformation of the foams. Due to cellular anisotropy, compressive strength $\left(\sigma_{10 \%}\right)$ was measured in parallel and perpendicular to the direction of growth of the PUR foam. Compressive strength (measured in the parallel and perpendicular direction) of PUR foams after adding $5 \mathrm{wt} \%$ of pine oil is at a similar level to $\sigma_{10 \%}$ PU-0. This may indicate that despite the slightly lower apparent density and larger cell size, the reactive hydroxyl group of $\alpha$-terpineol, which is the main component of pine oil, after reacting with the isocyanate group forms a stable structure. However, with

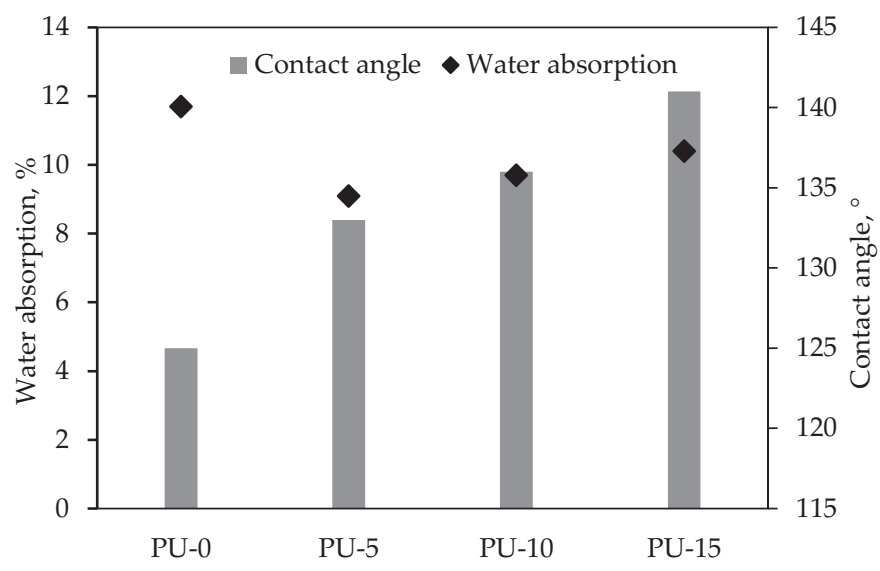

Fig. 5. Effect of contact angle on water absorption of RPUFs modified with pine needle oil an increase in pine needle oil content and changing morphology, these properties clearly deteriorate.

Analyzing the next results of mechanical properties, one can notice a visible correlation between apparent density and bending strength or impact strength. After introducing the modifier, these parameters deteriorate, where along with the increase in the amount of pine oil smaller values were obtained. Additionally, there is a visible increase in the flexibility of the modified foams. As a result, the foam composite creates a less rigid structure, thus increasing the energy absorption of the foam, resulting in even less impact strength.

For RPUFs, often used as construction materials affinity for water, is a very important parameter.

Pine needle oil significantly affected the hydrophobicity of foams (Fig. 5).

Regarding contact angles, it is noticeable that oil-modified foams have less wettability. The hydrophobicity of the samples increases as the oil content increases. Also, water absorption is lower in modified foams. However, there is no such linear tendency as in the case of contact angle measurements. This effect can be attributed to greater surface heterogeneity with a larger distribution of pore sizes in foams modified with a higher content of pine oil.

\section{CONCLUSIONS}

In the present study, RPUF was modified with needle oil in three contents (5, 10 and 15 wt \%). The effect of pine oil on foaming kinetics, morphology, physiochemical properties, hydrophobicity and antibacterial properties of the resulting RPUF composites were investigated. It has been observed that the introduction of essential oil has a significant effect on the morphology and further mechanical and thermal properties of RPUF. The addition of pine oil reduces the viscosity of the system, which 
translates into foam growth kinetics, but above all affects the deterioration of the morphology of the obtained foams by increasing the heterogeneity of the structure depending on the amount of additive. Oil-modified composites have a larger pore size and lower apparent density, which is reflected in the deterioration of mechanical properties. However, the lipophilic nature of the oil increases the hydrophobicity of the system, manifesting itself by increasing the contact angle and reducing the absorbability of RPUF. The most important aspect of adding pine oil is obtaining antibacterial properties, which increases the range of possibilities for using RPUFs in many areas of life.

\section{REFERENCES}

[1] Akindoyo J.O., Beg M.D.H., Ghazali S. et al.: RSC Advances 2016, 6, 114453. https://doi.org/10.1039/C6RA14525F

[2] Gama N.V., Ferreira A., Barros-Timmons A.: Materials (Basel) 2018, 11 (10), 1841. https://doi.org/10.3390/ma11101841

[3] Mondal P., Khakhar D.: Macromolecular Symposia 2004, 216, 241. https://doi.org/10.1002/masy.200451223

[4] Pugh R.: Advanced in Colloid Interface Science 2005, 114-115, 239. https://doi.org/10.1016/j.cis.2004.08.005

[5] Rightor E.G., Urquhart S.G., Hitchcock A.P. et al.: Macromolecules 2002, 35, 5873. https://doi.org/10.1021/ma0122627

[6] Villani M., Consonni R., Conetti M. et al.: Polymers 2020, 12 (2), 362. http://dx.doi.org/10.3390/polym12020362

[7] Xu L.-C., Siedlecki C.A.:"In Advances in Polyurethane Biomaterials", Elsevier, New York 2016, p. 247.
[8] Udabe E., Isik M., Sardon H. et al.: Journal of Applied Polymer Science 2017, 134, 45473. https://doi.org/10.1002/APP.45473

[9] Lundin J.G., Coneski P.N., Fulmer P.A., Wynne J.H.: Reactive and Functional Polymers 2014, 77, 39. https://doi.org/10.1016/j.reactfunctpolym.2014.02.004

[10] Coneski P.N., Weise N.K., Fulmer P.A., Wynne J.H.: Progress in Organic Coatings 2013, 76, 1376. https://doi.org/10.1016/j.porgcoat.2013.04.012

[11] Kugel A., Stafslien S., Chisholm B.J.: Progress in Organic Coatings 2011, 72, 222. https://doi.org/10.1016/j.porgcoat.2011.07.004

[12] Silvestre C., Duraccio D., Cimmino S.: Progress in Polymer Science 2011, 36, 1766. http://dx.doi.org/10.1016/j.progpolymsci.2011.02.003

[13] Kenawy E., Worley S.D., Broughton R.: Biomacromolecules 2007, 8, 1359. http://dx.doi.org/10.1021/bm061150q

[14] Macchioni F., Cioni P.L., Flamini G. et al.: Flavour and Fragrance Journal 2003, 18 (2), 139. https://doi.org/10.1002/ffj.1178

[15] Nazzaro F., Fratianni F., De Martino L. et al.: Pharmaceuticals, 2013, 6 (12), 1451. https://doi.org/10.3390/ph6121451

[16] Kairytė A., Vaitkus S., Vejelis S. et al.: Industrial Crops and Products 2018, 112, 119. https://doi.org/10.1016/j.indcrop.2017.11.027

[17] Członka S., Bertino M.F., Kośny J. et al.: Industrial Crops and Products 2018, 115, 40. https://doi.org/10.1016/j.indcrop.2018.02.019

[18] Sienkiewicz N., Członka S., Kairytė A., Vaitkus S.: Polymer Testing 2019, 79, 106046. https://doi.org/10.1016/j.polymertesting.2019.106046

[19] Zeng W.-C., Zhang Z., Gao H. et al.: Journal of Food Science 2012, 77, C824. http://dx.doi.org/10.1111/j.1750-3841.2012.02767.x

Received 25 V 2020. 